\title{
Chapter 3 \\ Commercializing Promising but Dormant Japanese Industry-University Joint Discoveries via Independent, Venture Capital Funded Spin-Offs
}

\author{
Robert Kneller
}

\begin{abstract}
This chapter outlines a way to foster science-based entrepreneurship and to develop some of the promising discoveries made jointly by Japanese universities and corporate researchers. The core proposal is to encourage the formation of independent, venture-capital-backed spin-offs based upon technologies jointly discovered by universities and companies that are lying dormant, but that have significant commercial potential. This chapter outlines the rationale for this proposal and a process for doing so. It discusses one spin-off that appears to be successful so farTeraView - spun off from Toshiba Research Europe and the Cavendish Laboratory of the University of Cambridge, as well as barriers to replicating this promising example. Ultimately, the success of this endeavor will depend upon established Japanese companies and university researchers both realizing that they stand to benefit. Success also depends upon altering longstanding practices in some industries related to intellectual property (IP) management, particularly the cross-sharing of IP rights and the reluctance to exclusively out-license technologies.
\end{abstract}

\section{First Rationale: New Companies Are Important for Innovation}

New companies (i.e., startups or venture companies) have proved to be superior compared to established companies in developing many innovative technologies, provided they can grow in an environment that is supportive of science-based entrepreneurship.

This is clear in the case of pharmaceuticals. A review of all the new drugs approved by the United States Food and Drug Administration between 1998-2007 clearly shows

\footnotetext{
R. Kneller $(\bowtie)$

Research Center for Advanced Science and Technology (RCAST),

The University of Tokyo, 4-6-1 Komaba, Meguro-ku, Tokyo, Japan

e-mail: kneller@tt.rcast.u-tokyo.ac.jp
} 
that new companies (biotechs) are much more likely than established pharmaceutical companies to undertake the initial development of innovative drugs-in other words, drugs that have a new physiological mechanism of action or new chemical structure, or drugs that offer significant health benefits over existing drugs [1]. This is especially true in the case of orphan drugs (which usually have small markets), biologics (complex protein drugs whose discovery is not amenable to mass screening techniques), and drugs discovered in universities. Indeed, it is extremely rare for pharmaceutical companies to undertake initial development of groundbreaking drugs discovered in universities. Instead, since about 1980 the world has relied upon new companies to undertake this development to bring such discoveries closer to public benefit.

Similarly, new companies are leaders in fields such as robotic surgery, gene sequencers, therapeutic biomedical devices, wireless medical monitoring devices, applications of stem cell technologies, lab-on-a-chip systems, 3-D printers, and, of course, Internet communications and social media. They are among the leading companies in industries such as vascular endoscopes, semiconductor manufacturing equipment, high efficiency solar cells, microelectromechanical systems (MEMS) sensors for high-stress environments, and wave energy power generation.

In Japan, one often hears the mantra that new companies cannot succeed in industries with high capital or manufacturing costs or where large companies are active [2]. Yet this common belief is belied by the semiconductor companies that rose to prominence in the 1980s, such as LSI Logic, VLSI Technology, Cypress Semiconductor, and Cisco Systems [3], and also by the companies that pioneered small hard disk drives, such as Seagate, Maxtor, and Western Digital that spun off from IBM [4]. The ability of new companies to succeed with new technologies while large companies with much greater resources fail, depends upon the new companies' ability to obtain large investments (usually from private venture capital), to protect their discoveries with patents and copyrights, and to outsource manufacturing. But their success is also often a result of large companies not perceiving the value of new technologies, considering the market for them to be too small, considering new technologies to be too removed from the needs of their main customers, and simply being too bureaucratic to develop them rapidly [4-6]. Henderson [7] suggests that, considering the internal competence of large firms and the way they are geared to meeting the needs of current customers, it may be rational for them to ignore innovative discoveries. This may be particularly true if they can outsource the risky development of innovative technologies to startups, on the assumption that they can buy the startups or partner with them, once the startups have shown proof of concept $[1,8]$.

\section{Second Rationale: Barriers to Science-Based Entrepreneurship in Japan}

In almost all the examples cited above of industries where startups are leaders, most of the leading startups are based in the United States. However, the pharmaceutical data show that not only America, but also Canada, Australia, Israel, and to a lesser 
extent, the United Kingdom, are countries where startups are lead innovators [1]. The patterns of pharmaceutical innovation for Japan and continental Europe, in particular Japan and Germany, are very similar. There, new drug discoveries occur almost exclusively in the in-house laboratories of established companies, and these drugs are generally not innovative.

There are some signs of startups playing a larger role in Japanese innovation. The number of Japanese biomedical therapies being developed by startups has increased. In 2004, about 135 Japanese biotechs were developing new medical therapies but only about five had new drugs (or other therapies) on the market or in clinical trials. Five years later in 2009, the number of therapeutic-oriented biotechs had decreased slightly (to about 115). However, these had about 45 new Japaninvented drugs, drug delivery systems, regenerative medicine therapies, or therapeutic vaccines on the market or in clinical trials. This is probably a higher number of domestic-origin therapies than from startups in any continental European country [1]. Also, more recent graduates of elite Japanese universities seem to be starting new companies than 10 years ago [9].

However, outside of biomedicine, progress is weaker. Few new companies with unique technologies that have international market potential seem to be on a growth trajectory. Without going into details, several companies that seemed to have growth potential have stalled. In some cases they have been overtaken by overseas startups. In other cases they have been slow to seek overseas markets and have been confined to alliances with Japanese companies. Moreover, since the 1990s, few if any spinoffs from established companies have succeeded in becoming leaders in Japan, much less in the global market. However, there have been many failures, often related to interference from the parents [6].

Numerous interrelated and complex factors make the environment for sciencebased entrepreneurship less supportive than in North America or Australia. Many of these are related to deeply rooted social and institutional factors of the type that distinguish liberal market economies (including the United States, Canada, and Australia) from coordinated market economies, such as Japan and continental Europe. ${ }^{1}$ A possible list might be as follows ${ }^{2}$ :

\footnotetext{
${ }^{1}$ Exactly in line with the pharmaceutical data above, liberal market economies are said to produce relatively more radical innovations while coordinated market economies tend to excel in incremental innovations. The greater propensity for new companies to undertake radical innovation, and the relatively more supportive environments for science-based entrepreneurship in liberal market as opposed to coordinated market economies, may be the missing link explaining this phenomenon. Liberal market economies are characterized by relatively high labor mobility, low job security, low reliance on in-house training, minimal government and organized labor involvement in business decisions, and a tendency for equity as opposed to loan financing for business expansion; while the opposite features characterize coordinated market economies [10].

${ }^{2}$ Along with the specifically cited references, see [6] for reasons $1-7$ and [11] for reasons 8-10.
} 
1. Low mobility for skilled professionals (hesitancy to work in startups and to change jobs)

2. Limited access to capital, in particular few angel investors and lack of business and technical expertise among venture capital (VC) investors

3. Preference in large companies for autarkic (self-reliant) innovation [12]

4. Tendency for Japanese startups to focus on the domestic markets and alliances and to ignore more competitive but more rewarding overseas opportunities - a tendency reinforced by language barriers and the dearth of personnel comfortable dealing with overseas organizations

5. Preemption of university IP and researchers' energy by large companies [13]

6. Limited preference for small businesses in Japanese government procurement, and a cumbersome Japanese government equivalent to the United States' SBIR program

7. Japanese entrepreneurs prefer service or value-chain companies to more confrontational and disruptive "gazelles"

8. The system of allocating government support for university R\&D (i.e., the way research proposals are solicited and selected for funding) creates disincentives to pursue innovative research

9. The system of patronage-based university recruitment and promotion similarly creates disincentives to pursue innovative university research

10. Cultural and institutional barriers to horizontal, inter-organizational information sharing and cooperation as described by Nakane [14]

Among these, probably the first is the most important. The close relationship between a fluid labor market, entrepreneurship, and innovation has been described by Saxenian [15], Hyde [16], and Fujimoto [17]. A fluid, or high velocity, labor market ensures that persons who join startups usually can continue their careers if their company fails. When combined with easy entry and exit of startups, a fluid labor market constantly reallocates the most precious resource of all-human capital-among companies where it is most needed and rewarded. It also creates a network where information is shared rapidly across organizational boundaries. It results in high dedication to work and high alignment of corporate and individual goals. All these factors decrease the perception of risk for investors contemplating investing in startups. The tendency for professionals to spend most of their careers in one or two companies is probably the single most important factor underlying the similarities between Japan and Germany with respect to entrepreneurship and innovation. Many of the factors that distinguish liberal and coordinated market economies impact labor mobility (footnote 1 and Hall and Soskice 2001 [10]).

The proposal at the heart of this chapter does not address labor mobility directly. However, if successful, it will go a long way towards creating a critical mass of mobile entrepreneurial scientists and managers that will address this most important issue. However, it does address the barriers listed above as 2, 3 and 5, as well as 4, provided overseas investors can be included in the spin-off process. In particular, barrier 5 is addressed by the following rationale for this proposal. 


\section{Third Rationale: The Number of Dormant Industry-University Joint Inventions Is Large}

Joint applications for patents covering industry-university collaborative research discoveries are the dominant form of technology transfer in Japan, vastly exceeding licenses of independently invented university discoveries. Since 2007, such joint applications have consistently accounted for about $60 \%$ of the approximately 9,000 total annual university patent applications to the Japan Patent Office (JPO). Because only a fraction of the remaining $40 \%$ of university applications are licensed, the ratio of jointly patented collaborative research inventions to inventions transferred under independent licenses is roughly 3:1 in major universities and probably even higher in lesser known universities. The vast majority of the industry co-owners of these patents are large Japanese companies [18, 19].

At the other end of the international patent application process, patents co-owned by Japanese universities and private companies account for about one third of all United States patents covering Japanese university inventions. ${ }^{3}$ The vast majority of these companies are established Japanese companies. This situation is probably unique among major industrialized countries. Only about $15 \%$ of German university inventions that have been awarded United States patents are co-owned by companies. For Canadian and United Kingdom university inventions, the proportions are about $10 \%$ and $6 \%$, respectively [19]. ${ }^{4}$

Having companies lined up as development partners for such a large proportion of university inventions may provide Japan a unique advantage. However, with coownership comes automatic control with no development incentives. Interviews with over 20 Japanese companies recently engaged in collaborations with universities indicate that many collaborative discoveries are not developed, or are not developed to anywhere near their full potential (Kneller et al. under review [21]).

This can be referred to as the "lock up" problem. It is partially alleviated by the fact that about half of Japanese joint industry-university patent applications are abandoned after 3 years and essentially dedicated to the public (Ministry of Education, Culture, Sports, Science \& Technology data compiled by Watanabe [18]). These are considered to be "defensive" patent applications because they are filed mainly to preempt

\footnotetext{
${ }^{3}$ This is based on reviewing a random $13 \%$ sample (68 patents) of all the approximately 525 US patents issued between June 2011 and May 2012, where at least one owner (assignee) is a Japanese university.

${ }^{4}$ The percentage of United States university patents that are co-owned by companies is less than $5 \%$. However, this is due in part to a unique aspect of United States patent law which permits patent co-owners to transfer their rights without the permission of other co-owners, thus making coownership of a United States patent equivalent to a transferable, royalty-free, non-exclusive license. In all other industrialized countries, the permission of all co-owners is necessary for any license or assignment, and thus co-ownership of a non-United States patent is equivalent to a non-transferable, royalty-free, exclusive license [20].
} 
rivals from patenting the same discovery and thus to preserve freedom to operate. This may increase the patent commons and reduce the patent thicket problem. However, the incentives for any company, particularly a startup, to invest substantial resources to exploit the full potential of these discoveries are greatly diminished once the discovery is publicized and patent protection is not available.

As for the joint research patent applications that are not abandoned, a fraction ${ }^{5}-$ about 175 over a recent 12-month period-issue as United States patents. A review of a sample of these jointly owned patents suggests that about half are narrow or cover manufacturing processes destined to be used by the sponsoring company. In other words, the lock-up danger is low. However, the remainder (currently about 90 United States patents issued annually) are broad patents that probably could be useful to several companies or represent potentially significant technical advances with a potentially significant market impact (note 3 ). If the company co-owners of these technologies do not try to develop them, or do not at least seriously look into the feasibility of development, this would represent a loss of potential future benefits to society and of past taxpayer support for the university research that led to these inventions. ${ }^{6}$ Presumably, some of the approximately 2,500 joint research inventions that are not abandoned but never issued as United States patents are similarly broad. Some companies have revealed that they apply for patents on some collaborative university discoveries to deny their use to rivals, even though they do not intend to develop the discoveries themselves [18].

These indications that lock-up is a significant problem for joint industry-university discoveries reflect a more general problem of technology hoarding in large Japanese manufacturing companies. In 2007, about $60 \%$ of Japanese manufacturing companies said that most of their technologies that they do not commercialize themselves are simply abandoned and are never made available to outside parties [2].

The following account describes one promising technology that would have been abandoned had not the company made a difficult, courageous, and probably also far-sighted decision to let the inventors and VC investors spin off an independent company to develop it.

\section{Case Example: TeraView}

TeraView was spun off in 2001 from the Cavendish Laboratory of the University of Cambridge's physics department (CCL) and Toshiba Research Europe (TRE). TRE was established in 1991 and its main laboratory was situated near CCL to facilitate

\footnotetext{
${ }^{5}$ See note 3. Based upon data in Watanabe [18], this fraction is probably between 5\% and $10 \%$.

${ }^{6}$ Corporate funding for joint research in Japan does not cover the salaries of full-time faculty, nor the tuition or stipends of graduate students, and only a fraction of infrastructure costs. It sometimes does cover costs of some special equipment and the salaries of a growing number of non-tenured so-called "project" assistants, associate and even some full professors. The former are often persons beginning their academic careers. Some of the latter are senior company scientists dispatched to the university. In general Japanese companies pay much less per collaborative research project than do American companies [6, 19].
} 
collaboration between these two laboratories. One of the joint research areas related to applications of terahertz frequency light. This revealed potential applications in fields such as dentistry, security (detection of weapons or explosives), pharmaceutical quality control, semiconductor manufacturing quality control, and cosmetics. However, Toshiba assessed that none of these applications were related to its core business and none would earn sufficiently large revenues to justify its moving into new development and business areas. Normally it would have abandoned the technology. However, two of the Cambridge scientists wanted to spin the terahertz technology off as a new company and one was eager to take on the responsibilities of an entrepreneurial company president.

TRE supported this plan in principle, reasoning that otherwise the technology would die (or at least not be developed for many more years). If TeraView became successful, Toshiba would benefit as a major stockholder. Also, it was not unreasonable to believe that there might be some synergies between Toshiba's and TeraView's operations and that some of the technologies TeraView might pioneer would be useful for Toshibaand that TeraView would turn to Toshiba for some of its equipment needs.

However, two issues that needed to be overcome were the longstanding principle among Japanese electronics companies that they not out-license exclusive rights to their IP (in this case, IP that had arisen from joint research with CCL) and also their longstanding practice of sharing among each other non-exclusive rights to some of their IP. In other words, Toshiba had to consider not only its own IP strategy, but also the expectations of other Japanese electronics companies. On the other side, the VC investors, whom TRE and the entrepreneurial CCL scientists had lined up, refused to invest if TeraView did not have exclusive rights to the patents covering its core technology. After an extended process, exclusive IP rights were granted and TeraView was established.

Today, most of its main projects are still in development phase and expenses still exceed revenues. However, employment has been growing and private investors have enough confidence in the company to provide it additional rounds of funding. Toshiba considers that the most important factor in overcoming the above-mentioned hurdles was the competence and enthusiasm of the Cambridge researchers who wanted to establish TeraView, particularly Donald Arnone, who is its CEO/President, and Dr. Michael Pepper, Director of CCL and founder of TeraView.

\section{Lessons from TeraView}

A recent Ministry of Economy, Trade and Industry study noted the small number of successful spin-offs from Japanese manufacturers and lack of support systems within such companies for entrepreneurial activity and spin-offs [2]. It also noted that Japanese managers tend to be risk averse. It advocated a low-risk low-return approach where spin-offs would not be independent from their parents and would continue to receive from them various forms of support [2]. These semi-independent spin-offs, where the parent retains control of key management decisions and which 
receive some financial, managerial, or marketing support from the parent are henceforth called "tethered" spin-offs.

However, the likelihood is probably small that this strategy will result in many companies that will develop innovative technologies and be successful in global markets. If manufacturers maintain control over their spin-offs (including their IP) this would almost certainly drive away potential overseas investors. As overseas investors are one of the main sources of networking with overseas customers, alliance partners and other investors, this would make overseas growth harder. Even Japanese VC investors would not like being in the position of passive investors. While the parent may regard forming a tethered spin-off as an opportunity for risk sharing, Japanese VC investors would be hesitant to share substantial risks under such circumstances, and they would be unlikely to invest in a novel technology such as terahertz. Furthermore, case study analyses from both the United States [22, 23] and Japan [6] suggest that spin-offs that are controlled by their parents usually fail-unless, as in the case of Fanuc spinning off from Fujitsu, the spin-off's operations already have substantial sales at the time of formation. The most common reason is that continuing control by the parent over management decisions usually vitiates the advantages of nimbleness and ability to seek freely funding and customers that are vital to the success of most startups.

With these barriers to tethered spin-offs in mind, the TeraView model of creating a truly independent VC-backed spin-off might be the most practical way to develop the large number of dormant inventions that are not being developed by large companies. It might also be the most likely way the parent will benefit from its dormant technologies - technologies that probably would otherwise die or languish undeveloped for many years.

Even though the spin-off would be independent, the parent would probably benefit from its success in several ways. First, the parent would likely hold $20 \%$ or more of the spin-off's stock in return for having licensed to it the core IP and possibly also having made cash investments [23]. The parent may have a seat on the board of the directors. Even if it did not, the parent would be able to keep track of its R\&D progress. The spin-off would likely turn to the parent, when possible, for equipment and services. At least in the case of large American IT companies, such as IBM, Intel, Cisco, and Qualcomm, spin-offs and other startups have often come to supply the parent with technologies it needs $[8,16]$. The VC investors probably would insist on the right to sell the startup or to take the startup public through an initial public offering of its stock. However, the parent may have the right to buy the spinoff at a set period of time (e.g., 3 years) following its formation. If the parent seconded some of its researchers to the startup, the parent's influence would increase and the spin-off might come to resemble a joint venture between the parent and the $\mathrm{VC}$ investors. In the process, the parent would gain valuable entrepreneurial experience.

The founders would very likely come from universities and managers would be recruited by VC investors. This would avoid the problem noted in the METI study that company employees often perceive the risks associated with leaving the mother company are too high [2]. In general, VC investors would consider investing 
in a spin-off to be less risky than investing in startups based only on independent university research, provided the parent company had done its own evaluation of the university discovery, and especially if it had carried out development work and moved the discoveries closer to proof of concept.

In any case, the initiative for starting a spin-off may have to come from university researchers who understand the technology, know that the company is not developing it, and know whom to approach in the company. If the company is interested in exploring the possibility, the university or the university inventors may have to take the lead in contacting VC investors. From this point on, the structure of the agreement spinning off the company will probably have to be worked out by the parent, VC investors, and founders, with the university playing a facilitating role. The prospective parent company should always have the right to say it does not want to go through with a spin-off.

However, to preserve the parent's option of forming a spin-off, universities ought to require that any sublicenses (even of only non-exclusive rights) of jointly owned inventions be made only with the universities' prior approval. As joint owners, universities have this right under Article 73 of Japan's Patent Law (note 4). They ought not to give up it up. Universities should permit the collaborating company to grant non-exclusive sublicenses only if there are clear public policy reasons to do so, and they ought not to permit such sublicenses if it appears that the company probably will not develop the discovery, but that some other company (especially a startup) might be able to do so.

\section{Conclusion}

The story of TeraView is consistent with Christiansen's accounts [4, 5] of how large companies often fail to develop new technologies. This comes about because companies do not perceive their value, think the market is too small, consider the technologies to be too removed from their main business or main customer needs, or simply are too bureaucratic to develop them rapidly. The unusual aspect of the TeraView case is that Toshiba agreed to let TeraView have exclusive rights to the startup's core IP. This provides a model for how more Japanese spin-offs can grow successfully.

This chapter noted the dearth of promising Japanese startups outside of biomedicine and the many barriers facing spin-offs and other startups in Japan. Considering these difficulties, Japan could basically give up on startups and concentrate on improving relations between universities and established companies, hoping that the established companies will turn themselves around and produce market breakthroughs with a series of fundamentally new technologies. However, recent trends, the evidence of hoarding of dormant technologies by manufacturing companies and their frequent reluctance to enter new technical fields, plus the analyses of Christensen and Henderson cited above, all suggest this will not come to pass. Moreover, as countries such as China increase their ability to produce high quality 
manufactured products at a substantially lower price than Japanese manufacturers, Japanese industry as a whole risks being trapped between these technically advancing lower-cost manufacturers and overseas companies that can stay ahead by developing breakthrough innovations.

Particularly with respect to the development of university discoveries where startups are proven to be more successful than established companies, Japan needs to foster the growth of more science-based startups. Mobilizing some of the many dormant but promising university discoveries arising under joint research by spinning off independent companies and letting VCs and entrepreneurs undertake the risk of development is one of the best ways to tackle this problem.

Open Access This article is distributed under the terms of the Creative Commons Attribution Noncommercial License which permits any noncommercial use, distribution, and reproduction in any medium, provided the original author(s) and source are credited.

\section{References}

1. Kneller R (2010) Importance of new companies for drug discovery: origins of a decade of new drugs. Nat Rev Drug Discov 9:867-882

2. Study Committee on Large Enterprise Ventures (2008) Proposal by the Study Committee on Large Enterprise Ventures: Win-win growth for both large enterprises and ventures. (English version http://www.jates.or.jp/Z-Temp/METI_English080616.pdf). (Japanese version http:// www.jates.or.jp/Z-Temp/METI_Report_080409.pdf). Accessed 24 Oct 2012

3. Hall B, Ziedonis R (2003) The patent paradox revisited: a empirical study of patenting in the US semiconductor industry, 1979-1995. RAND J Econ 32:101-128

4. Christensen CM (1993) The rigid disk drive industry: a history of commercial and technological turbulence. Bus Hist Rev 67:531-588

5. Christensen CM (1997) The innovator's dilemma, when new technologies cause great firms to fail. Harvard Business School Press, Boston

6. Kneller R (2007) Bridging islands: venture companies and the future of Japanese and American industry. Oxford University Press, Oxford

7. Henderson R (2006) The innovator's dilemma as a problem of organizational competence. J Prod Innov Manag 23:5-11

8. Chesborough H (2003) Open innovation: the imperative for creating and profiting from technology. Harvard Business School Press, Boston

9. Eberhart R, Eesley C (2012) Failure is an option: institutional reform, bankruptcy, and new firm performance. Stanford Graduate School of Business working paper. http://sprie.gsb.stanford. edu/publications/failure_is_an_option_institutional_reform_bankruptcy_and_new_firm_ performance/. Accessed 24 Oct 2012

10. Hall PA, Soskice D (2001) An introduction to varieties of capitalism. In: Hall PA, Sosckice DW (eds) Varieties of capitalism: the institutional foundations of comparative advantage. Oxford University Press, Oxford

11. Kneller R (2010) The changing governance of Japanese public science. In: Whitley R, Glaser J, Engvall L (eds) Reconfiguring knowledge production: changing authority relations in the sciences and their consequences for intellectual innovation. Oxford University Press, Oxford

12. Kneller R (2003) Autarkic drug discovery in Japanese pharmaceutical companies: insights into national differences in industrial innovation. Res Policy 32:1805-1827

13. Kneller R (2006) Japan's new technology transfer system and the preemption of university discoveries by sponsored research and co-inventorship. J Assoc Univ Technol Managers 18(1): 15-35. Republished with permission in Industry and Higher Education 21 (no. 3, June 2007) 
14. Nakane C (1972) Japanese society. University of California Press, Berkeley (Japanese version (1967) Tate-shakai no ningen kankei. Kodansha, Tokyo)

15. Saxenian AL (1994) Regional advantage: culture and competition in Silicon Valley and Route 128. Harvard University Press, Cambridge

16. Hyde A (2003) Working in Silicon Valley. M E Sharpe, Armonk, NY

17. Fujimoto M (2011) Trends in changing jobs by professional personnel in high mobility regions-The case of Silicon Valley, U.S. Institute for Technology, Enterprise and Competitiveness, Doshisha University, Working paper 11-02 (Japanese version (2012) Doshisya Syakaigaku Kenkyu (16):17-36)

18. Watanabe T (2012) Sangaku renkei ni kansuru ikutsu ka no ronten - Inobēshon ni shisuru sangaku renkei no tame ni [Issues related to industry-university collaboration-towards cooperation that supports innovation]. Presentation to the Committee for the Promotion of IndustryAcademic-Government Collaboration of the Ministry of Education, Culture, Sports Science and Technology (MEXT), Tokyo, Japan, on 2 July 2012 (in Japanese)

19. Kneller R (2011) Invention management in Japanese universities and its implications for innovation: insights from the University of Tokyo. In: Wong PK (ed) Academic entrepreneurship in Asia: the role and impact of universities in national innovation systems. Edward Elgar, Cheltenham, pp 69-85

20. LaFrance M (2005) A comparative study of United States and Japanese laws on collaborative inventions, and the impact of those laws on technology transfers. Scholarly works. Paper 436. http://scholars.law.unlv.edu/facpub/436

21. Kneller R, Mongeon M, Cope J, Garner C, Ternouth P. Industry-university collaborations in Canada, Japan, the UK and USA-with emphasis on intellectual property, publication freedom, and managing the lock-up problem. (under publication review)

22. Chesborough HW (2000) Designing corporate ventures in the shadow of private venture capital. Calif Manag Rev 42(2):31-49

23. Laurie D (2001) Venture catalyst: the five strategies for explosive corporate growth. Perseus Books, Cambridge 